\title{
Rhabdomyolysis Associated with Opiate Abuse: A Case Report
}

\author{
Opioid Kötüye Kullanımına Bağlı Rabdomiyoliz: Olgu Sunumu
}

Mustafa Gülpembe', Demet Acar', Nazire Belgin Akıllı1', Saniye Göknil Çalık', Yahya Kemal Günaydın', Ramazan Köylü', Başar Cander²

'Department of Emergency Medicine, Konya Training and Research Hospital, Konya, Turkey

2Department of Emergency Medicine, Necmettin Erbakan University Faculty of Medicine, Konya, Turkey

\section{ABSTRACT}

Introduction: There are several complications associated with opiate abuse, including respiratory suppression, disturbance of consciousness, aspiration pneumonia, pulmonary edema, myocarditis, rhabdomyolysis, and compartment syndrome. Some of these complications may be life-threatening.

Case Report: Herein, we present a case of rhabdomyolysis due to opiate abuse in a young man. Rhabdomyolysis is a known but rare complication of intravenous opiate abuse.

Conclusion: Because rhabdomyolysis may be life-threatening, and prompt diagnosis and treatment are essential, physicians should be aware of this complication among opioid addicts.

Keywords: Rhabdomyolysis, opioid abuse, case

Received:06.11.2014 Accepted:07.01.2015

Available Online Date: 27.02.2015

\section{ÖZET}

Giriş: Opioid kötüye kullanımı ile ilişkili pek çok komplikasyon bildirilmiştir. Bunların arasında solunum depresyonu, bilinç bulanıklığı, aspirasyon ğnömonisi, pulmoner ödem, miyokardit, rabdomiyoliz ve kompartman sendromu sayılabilir. Bu komplikasyonların bazıları hayatı tehdit eder.

Olgu Sunumu: Burada genç bir erkek hastada opioid kötüye kullanımına bağlı gelişen rabdomiyoliz vakası sunacağız.

Sonuç: Rabdomiyoliz intravenöz opioid kötüye kullanımına bağlı nadir görülen bir komplikasyondur. Rabdomiyoliz hayatı tehdit edebilecek sonuçlar doğurabileceği için erken tanı ve tedavisi çok önemlidir. Bu nedenle klinisyenler opioid kullanıcılarında bu komplikasyona karşı uyanık olmalılardır.

Anahtar Kelimeler: Rabdomiyoliz, opioid kötüye kullanımı, olgu

Geliş Tarihi: 06.11.2014 Kabul Tarihi: 07.01.2015

Çevrimiçi Yayın Tarihi: 27.02.2015

\section{Introduction}

There are several complications associated with opioid abuse, including respiratory suppression, disturbance of consciousness, aspiration pneumonia, pulmonary edema, myocarditis, rhabdomyolysis, and compartment syndrome (1). Some of these complications may be life-threatening.

Rhabdomyolysis is a disorder caused by toxic substances such as creatine kinase (CK) and myoglobin released from damaged muscle tissue. Drug use or overdosage of some drugs such as cocaine, amphetamines, statins, and heroin has been associated with rhabdomyolysis (2). Herein, we present a case of rhabdomyolysis due to opioid abuse in a young man.

\section{Case Report}

A 21-year-old man who was found unconsciousness was admitted to the emergency department (ED). He was a night watchman and was found by his friends in the morning at work lying on the ground. Clinical examination revealed tachycardia of 124 bpm and blood pressure of $90 / 60 \mathrm{mmHg}$. His body temperature was $38.5^{\circ} \mathrm{C}$. Initially, his complete blood count white blood cell count was $24.9 \times 10^{9} / \mathrm{L}$, hemoglobin level was $14.3 \mathrm{~g} / \mathrm{dL}$, and arterial blood gas analysis revealed mixed metabolic and respiratory acidosis $\left(\mathrm{pH}=7.23, \mathrm{PCO}_{2}=50 \mathrm{mmHg}, \mathrm{HCO}_{3}=20.1 \mathrm{~mm}\right.$ ). His biochemical data are summarized in Table 1. The multidrug test 
Table 1. Laboratory data of patient on different days of his hospitalization

\begin{tabular}{|c|c|c|c|c|c|c|}
\hline Laboratory Parameter & $1^{\text {st }}$ day & $2^{\text {nd }}$ day & $3^{\text {rd }}$ day & $4^{\text {th }}$ day & $5^{\text {th }}$ day & $6^{\text {th }}$ day \\
\hline Urea (mg/dL) & 54 & 62 & 59 & 97 & 100 & 71 \\
\hline Creatinine(mg/dL) & 2.6 & 3.0 & 3.9 & 6.3 & 7.2 & 5.3 \\
\hline ALT (U/L) & 268 & 447 & 394 & 305 & 190 & 174 \\
\hline AST (U/L) & 761 & 2172 & 2306 & 1749 & 787 & 744 \\
\hline GGT (U/L) & 47 & 65 & 28 & 51 & 68 & 79 \\
\hline$A L P(U / L)$ & 86 & 99 & 65 & 77 & 96 & 95 \\
\hline CK (U/L) & & 221800 & 124700 & 85400 & 20550 & 20340 \\
\hline CK-MB (U/L) & 4489 & 3220 & 1240 & 800 & 2114 & 170 \\
\hline Troponin I & 15.6 & 50.8 & 16.2 & 9.5 & 3.6 & 0.7 \\
\hline $\mathrm{LDH}(\mathrm{U} / \mathrm{L})$ & 1981 & 2011 & 2683 & 2162 & 1714 & 1515 \\
\hline Sodium (mEq/L) & 145 & 137 & 135 & 131 & 129 & 132 \\
\hline Potassium (mEq/L) & 7.9 & 5.3 & 4.1 & 3.9 & 3.6 & 3.5 \\
\hline Calcium (mEq/L) & 6.4 & 6.4 & 5.8 & 6.2 & 7.0 & 7.2 \\
\hline Phosphor (mEq/L) & 12.2 & 2.3 & 4.0 & 4.2 & 3.9 & 5.0 \\
\hline
\end{tabular}

performed for toxicology was positive for opioid. A few hours after treatment in ED, he awoke, and his physical examination revealed no abnormal findings, except for a slight power loss in the left leg. He was not known to have any history of systemic diseases. He was asked regarding opioid usage, and he replied that he was using opioids for 2 years. After stabilizing his hemodynamic status, he was transferred to the intensive care unit (ICU). His urinary test and posteroanterior lung graph were normal. Brain computed tomography (CT) (Somatom Sensation 16 software version A50, Siemens, Forchheim, Germany) and diffusion magnetic resonance imaging (MRI) (Avanto, Siemens Medical Systems, Erlangen, Germany) performed to determine the cause of unconsciousness were all normal. The neurology department evaluated the patient and did not identify any sign of central nervous system infection. Due to fever and increased white blood cell count, ceftriaxone $2 \times 1$ gr intravenously was started as prophylaxis. Owing to the power loss noted in his left leg in neurological examination, vertebral $\mathrm{CT}$ and pelvic and left femur direct graphs were performed, which were also normal. In soft tissue ultrasound (Antares, Siemens AG, Medical Solutions Henkestr, Erlangen, Germany) examination of the left femur, minimal fluid accumulation compatible with a hematoma was observed, and this was followed-up by orthopedists without any treatment. Although his electrocardiography was normal, his cardiac markers [Troponin I, creatinine kinase (CK), CK-MB] were high at admission and followup. The cardiology department determined that this increase was a result of opioid abuse, but this department could not exclude acute coronary syndrome, and acetylsalicylic acid $1 \times 100 \mathrm{mg}$, clopidogrel $1 \times 1$, carvedilol $2 \times 6.25 \mathrm{mg}$ per oral, and enoxaparin sodium $2 \times 0.6$ cc sc were started. On the $2^{\text {nd }}$ day of his hospitalization, his urinary output decreased, and he developed hematuria. He was diagnosed with rhabdomyolysis, and 'crush fluid' treatment was started to him.
On the $6^{\text {th }}$ day of his follow-up, he was transferred to the nephrology ward and diagnosed with rhabdomyolysis and accompanying focal segmental glomerulosclerosis. With fluid resuscitation, his condition improved; his renal functions improved, and hemodialysis was not required. He was discharged from the hospital on the $15^{\text {th }}$ day of his hospitalization. The patient's informed consent was obtained before the preparation of this report.

\section{Discussion}

Opioid abuse is a problem commonly encountered in ED. In a recent retrospective, population-based study, middle age, male sex, public insurance, lower household income, and comorbidities (such as chronic pulmonary and neurological diseases) were determined to be associated with frequent (2 or more) ED visits. Moreover, in this cohort, frequent ED visits for opioid overdose were reported to be associated with a higher likelihood of future hospitalizations and near-fatal events (3). Opioid use may result in mental depression, depressed cardiac and respiratory function, skin flushing, dry mouth and nausea, peripheral nervous system injury, rhabdomyolysis, and compartment syndrome (4). Rhabdomyolysis is a known but rare complication of intravenous opioid abuse (5). It may be caused by muscle injury including postural muscle compression when comatose or an allergic or toxic reaction to opioid or its adulterants (6). Dehydration, vascular insufficiency, vasoconstriction, shock, trauma, seizure, acidosis, and a direct toxic effect may also be the causes contributing to the establishment of opioid associated rhabdomyolysis (7).

Rhabdomyolysis is a potentially life-threatening syndrome because it can result in electrolyte disturbances, arrhythmia, acute renal failure, and compartment syndrome. Boulanger-Gobeil et al. (8) reported a 22-year-old woman who was brought to ED following several 
episodes of tonic-clonic seizures a few hours after ingesting "legal ecstasy" and who developed prolonged rhabdomyolysis requiring 6 days of hospitalization. The diagnosis of rhabdomyolysis relies on the clinical and laboratory findings. In laboratory investigations, serum total creatinine kinase levels and myoglobin in urine are important to determine the presence of rhabdomyolysis in case of occurrence of its signs (9). Hypovolemia, aciduria, and increased urinary myoglobin excretion may contribute to the nephrotoxic effects of rhabdomyolysis (10). Kosmadakis et al. (2) prospectively evaluated the severity of rhabdomyolysis and acute renal failure in narcotic drug users and reported that rhabdomyolysis and acute renal failure were more severe in heroin users compared with the nonheroin users. In the presence of acute renal failure, the keystone of treatment is aggressive volume resuscitation and expansion of the extracellular fluid compartment to diminish the effects of myoglobin and prevent progression to acute renal failure. Other treatment modalities include the use of bicarbonate in an attempt to alkalinize the urine and mannitol. Electrolyte disturbances should be evaluated carefully and treated on time. Acute hemodialysis may also be required in some cases.

\section{Conclusion}

Because rhabdomyolysis may be life-threatening, and prompt diagnosis and treatment is essential, physicians should be aware of this complication among opioid addicts.

Informed Consent: Written informed consent was obtained from patient's relative who participated in this case.

Peer-review: Externally peer-reviewed.

Author Contributions: Concept - M.G., D.A.; Design - M.G., D.A., N.B.A., S.G.C.., Y.K.G., R.K., B.C.; Supervision - M.G., D.A., N.B.A., S.G.Ç., Y.K.G., R.K., B.C.; Materials - M.G., D.A., N.B.A., S.G.Ç., Y.K.G., R.K., B.C.; Data Collection and/or Processing M.G., D.A., N.B.A., S.G.C.., Y.K.G., R.K., B.C.; Analysis and/or Interpretation - M.G., D.A., N.B.A., S.G.Ç., Y.K.G., R.K., B.C.; Literature Review - M.G., D.A., N.B.A., S.G.Ç., Y.K.G., R.K., B.C.; Writer - M.G., D.A.; Critical Review - M.G., D.A. ,N.B.A., S.G.Ç., Y.K.G., R.K., B.C..

Conflict of Interest: The authors declared no conflict of interest.

Financial Disclosure: The authors declared that this study has received no financial support.
Hasta Onamı: Yazılı hasta onamı bu olguya katılan hastanın yakınından alınmıştır.

\section{Hakem değerlendirmesi: Dış bağımsı.}

Yazar Katkıları: Fikir - M.G., D.A.; Tasarım - M.G., D.A., N.B.A., S.G.Ç., Y.K.G., R.K., B.C.; Denetleme - M.G., D.A., N.B.A., S.G.Ç., Y.K.G., R.K., B.C.; Malzemeler M.G., D.A. N.B.A., S.G.Ç., Y.K.G., R.K., B.C.; Veri toplanması ve/veya işlemesi - M.G., D.A., N.B.A., S.G.C.,, Y.K.G., R.K., B.C.; Analiz ve/veya yorum - M.G., D.A., N.B.A., S.G.Ç., Y.K.G., R.K., B.C.; Literatür taraması - M.G., D.A., N.B.A., S.G.Ç., Y.K.G., R.K., B.C.; Yazıyı yazan M.G., D.A.; Eleştirel İnceleme - M.G., D.A., N.B.A., S.G.Ç., Y.K.G., R.K., B.C..

Çıkar Çatışması: Yazarlar arasında herhangi bir çıkar çatışması yoktur.

Finansal Destek: Bu çalışma için herhangi bir finansal destek alınmamıştır.

\section{References}

1. Sporer KA. Acute heroin overdose. Ann Intern Med 1999; 130: 584-90. [CrossRef]

2. Kosmadakis G, Michail O, Filiopoulos V, Papadopoulou P, Michail S. Acute kidney injury due to rhabdomyolysis in narcotic drug users. Int J Artif Organs 2011; 34: 584-8. [CrossRef]

3. Hasegawa K, Brown DF, Tsugawa Y, Camargo CA Jr. Epidemiology of emergency department visits for opioid overdose: a population-based study. Mayo Clin Proc 2014; 89: 462-71. [CrossRef]

4. Radovanović MR, Milovanović DR, Ignjatović-Ristić D, Radovanović MS. Heroin addict with gangrene of the extremities, rhabdomyolysis and severe hyperkalemia. Vojnosanit Pregl 2012; 69: 908-12. [CrossRef]

5. Hsu WY, Chiu NY, Liao YC. Rhabdomyolysis and brain ischemic stroke in a heroin-dependent male under methadone maintenance therapy. Acta Psychiatr Scand 2009; 120: 76-9. [CrossRef]

6. Kumar R, West DM, Jingree M, Laurence AS. Unusual consequences of heroin overdose: rhabdomyolysis, acute renal failure, paraplegia and hypercalcaemia. Br J Anaesth 1999; 83: 496-8. [CrossRef]

7. Richards JR. Rhabdomyolysis and drugs of abuse. J Emerg Med 2000; 19: 51-6. [CrossRef]

8. Boulanger-Gobeil C, St-Onge M, Laliberté M, Auger PL. Seizures and hyponatremia related to ethcathinone and methylone poisoning. J Med Toxicol 2012; 8: 59-61. [CrossRef]

9. Mas-Morey P, Visser MH, Winkelmolen L, Touw DJ. Clinical toxicology and management of intoxications with synthetic cathinones ("bath salts"). J Pharm Pract 2013; 26: 353-7. [CrossRef]

10. O'connor G, Mcmahon G. Complications of heroin abuse. Eur J Emerg Med 2008; 15: 104-6. [CrossRef] 